\title{
Impact of Entrepreneurship Activity Sustainable Development
}

\section{Wpływ działalności przedsiębiorczej na zrównoważony rozwój}

\section{Ivona Huđek, Barbara Bradač Hojnik}

\author{
University of Maribor, Faculty of Economics and Business, \\ Razlagova 14, 2000 Maribor, Slovenia \\ E-mails: ivona.hudjek1@um.si; barbara.bradac@um.si
}

\begin{abstract}
Sustainable development considers the development that achieves the present economic goals, without obstructing the future development in a sense of satisfying the needs of society and endangering the environment. Recently, the entrepreneurship phenomenon has been widely recognized as an important path towards sustainable development, positively contributing to the development of society. Thus, in the paper, the empirical evidence on linkages between entrepreneurial activity indicators and social development goals is provided. To examine the linkages, the data from the Global Entrepreneurship Monitor and Sustainable Development Goals Index were used. The empirical results suggest that entrepreneurship represents an important factor for fostering sustainability, particularly in opportunity-driven and innovative entrepreneurial activities. The results show, that both of them have a positive impact on sustainable development, while the necessity-driven entrepreneurial activity negatively affects sustainable development. This could be explained by the fact that necessity entrepreneurs are not likely to become the entrepreneurs to implement a promising business opportunity, but rather to earn an income. To achieve the sustainable development goals as well as entrepreneurship should become the national priority by introducing new policies and measures, that is, making the conditions, through which entrepreneurship could achieve positive contributions to the development of the society.
\end{abstract}

Key words: sustainable development, opportunity-driven entrepreneurial activity, innovative entrepreneurial activity, necessity-driven entrepreneurial activity, Sustainable Development Goals Index

\section{Streszczenie}

Zrównoważony rozwój to taki, który osiąga obecne cele gospodarcze, nie utrudniając przyszłego rozwoju w sensie zaspokajania potrzeb społeczeństwa i narażania środowiska. Ostatnio zjawiska przedsiębiorczości zostały powszechnie uznane za ważną ścieżkę do zrównoważonego rozwoju, która pozytywnie przyczynia się do rozwoju społeczeństwa. Dlatego w artykule przedstawiono empiryczne dowody na powiązania między wskaźnikami aktywności przedsiębiorczej a celami rozwoju społecznego. Do zbadania powiązań wykorzystano dane z Globalnego Monitora Przedsiębiorczości i Indeksu Celów Zrównoważonego Rozwoju. Wyniki empiryczne sugerują, że przedsiębiorczość stanowi ważny czynnik wspierający zrównoważony rozwój, szczególnie w przypadku działań zorientowanych na możliwości i innowacyjnych działań przedsiębiorczych. Wyniki pokazują, że oba te czynniki mają pozytywny wpływ na zrównoważony rozwój, a przedsiębiorczość zorientowana na konieczność negatywnie wpływa na zrównoważony rozwój. Można to wyjaśnić faktem, że przedsiębiorcy zorientowani na konieczność prawdopodobnie nie podążą w kierunku realizacji obiecujących nowych możliwości biznesowych, ale raczej w celu uzyskania dochodu. Aby osiągnąć cele zrównoważonego rozwoju, jak również przedsiębiorczość, powinny się one stać priorytetem krajowym poprzez wprowadzenie nowych polityk i środków, co oznacza stworzenie warunków, dzięki którym przedsiębiorczość mogłaby osiągnąć pozytywny wkład w rozwój społeczeństwa.

Słowa kluczowe: zrównoważony rozwój, działalność przedsiębiorcza zorientowana na możliwości, innowacyjna działalność przedsiębiorcza, działalność przedsiębiorcza zorientowana ka konieczności, indeks celów zrównoważonego rozwoju 


\section{Introduction}

The sustainable development is widely recognized as a path to achieve connections among economic, social, and environmental systems equally not only for the present, but also for future generations (e.g. Patzelt \& Shepherd, 2011; Cobbinah et al., 2011). In view of various definitions and thoughts about sustainable development, the United Nations provides one of the most common used definition according to which the sustainable development is development that meets the needs of the present without compromising the ability of future generations to meet their own needs (Emas, 2015). In other words, sustainable development implies such a development of a society that satisfies human needs with available resources, while not endangering natural systems and the environment. Sustainable development represents the way of production and consumption that takes into account the natural resources of the ecosystem within which these processes take place.

The sustainable development and entrepreneurship have been widely recognized in the literature and on a policy level as well as in business practice. The review of the literature on sustainable entrepreneurship shows, that it provides solutions for various environmental and social concerns (Hall et al., 2010). However, the research topic on sustainable development from an entrepreneurship perspective is relatively recent, merely present from 2002 and developed especially in the last decade (Kardos, 2012). Entrepreneurship phenomena has been addressed as an important path towards sustainable development by several authors (Cohen \& Winn 2007; York \& Venkataraman, 2010; Domańska et al., 2018). According to Stefanescu \& On (2012), both entrepreneurship and sustainable development are considered as solutions, positively contributing to the development of society.

Considering that the topic on sustainable development and entrepreneurship is relatively new, there still exists research gaps on a holistic approach combining linkages between the entrepreneurship activity and the economic, environmental, and social goals of sustainable development (Dhahri \& Omri, 2018) and on focusing on empirical findings. Refereed to the above-mentioned gap, the purpose of this study is to provide additional empirical evidence on linkages between entrepreneurship and sustainable development. The research goal of the paper is to empirically test linkages between the entrepreneurial activity indicators and social development goals. Hence, the main research question is: what is the correlation and impact of entrepreneurial activity on sustainable development? The paper is structured as follows. First, a review of the concept of sustainable development and the relation with entrepreneurship are provided together with hypotheses development. Second, the research methodology and the data used are described. Third, empirical findings with discussion are presented, followed by conclusions and implications for entrepreneurship and sustainable development.

\section{Theory background and hypotheses develop- ment}

The goal of sustainable development tends to economic efficiency (economic development), social responsibility (social progress) and environmental protection. The three elements are called the pillars of sustainable development and present so-called triple-bottom-line approach, merged in an integrated framework (Elkington, 1998; Hart \& Milstein, 2003). The triple-bottom-line approach has been used from a different point of views and analysed on different levels of analysis. On the organizational level, it is the idea, that it is possible to develop an organization in a way that not only earns financial profits, but at the same time also improves people's lives and helps the planet from an environmental viewpoint. Using the holistic approach, the society is completely dependent on Earth's resources, and to maximize the quality of life, it uses economic models. The economy is managed by the society and is dependent on natural resources. Therefore, the pillars of sustainable development cannot stand isolated without affecting each other. The overall objective of sustainable development is to provide a framework for the design of policies and strategies of continuous economic and social progress by considering the scarcity of natural resources. Its implementation should be following specific opportunities, conditions and circumstances of different parts of the planet (Gerlach, 2003; Kardos, 2012).

To measure the results of sustainable development, several approaches, developed measures and indexes were used. To compare sustainable development on an international or global level, the Sustainable Development Goals (SDG) can be used, which measure and summarizes countries' current performance and trends on 17 goals referring their sustainable development (goals are provided in Table 1). Sustainable Development Goals are measured by the SDG Index. Its score signifies the country's position between the worst (0) and the best or target (100) outcomes. In the year 2018, according to the SDG Index, the best scored is Sweden, followed by Denmark and Finland, whereas the Democratic Republic of Congo, Chad and the Central African Republic rank last among the 156 countries included in the rating (Sachs et al., 2018).

Recently, the researchers around the world are investigating how entrepreneurship can affect the sustainable economy and thus sustainable development. Both entrepreneurship and sustainable development are considered as solutions to assure the future development of the entire society. 
Table 1. The Sustainable Development Goals (Sachs et al., 2018)

\begin{tabular}{|c|c|}
\hline Goal & Description \\
\hline 1. No poverty & $\begin{array}{l}\text { Economic growth must be in- } \\
\text { clusive to provide sustainable } \\
\text { jobs and promote equality. }\end{array}$ \\
\hline 2. Zero hunger & $\begin{array}{l}\text { The food and agriculture sector } \\
\text { offers key solutions for devel- } \\
\text { opment, and is central for hun- } \\
\text { ger and poverty eradication. }\end{array}$ \\
\hline $\begin{array}{l}\text { 3. Good health } \\
\text { and well-being }\end{array}$ & $\begin{array}{l}\text { Ensuring healthy lives and pro- } \\
\text { moting the well-being for all at } \\
\text { all ages is essential to sustaina- } \\
\text { ble development. }\end{array}$ \\
\hline 4. Quality education & $\begin{array}{l}\text { Obtaining a quality education is } \\
\text { the foundation to improving } \\
\text { people's lives and sustainable } \\
\text { development. }\end{array}$ \\
\hline 5. Gender equality & $\begin{array}{l}\text { Gender equality is not only a } \\
\text { fundamental human right, but a } \\
\text { necessary foundation for a } \\
\text { peaceful, prosperous and sus- } \\
\text { tainable world. }\end{array}$ \\
\hline $\begin{array}{l}\text { 6. Clean water } \\
\text { and sanitation }\end{array}$ & $\begin{array}{l}\text { Clean, accessible water for all } \\
\text { is an essential part of the world } \\
\text { we want to live in. }\end{array}$ \\
\hline $\begin{array}{l}\text { 7. Affordable } \\
\text { and clean energy }\end{array}$ & $\begin{array}{l}\text { Energy is central to nearly } \\
\text { every major challenge and op- } \\
\text { portunity. }\end{array}$ \\
\hline $\begin{array}{l}\text { 8. Decent work } \\
\text { and economic } \\
\text { growth }\end{array}$ & $\begin{array}{l}\text { Sustainable economic growth } \\
\text { will require societies to create } \\
\text { the conditions that allow people } \\
\text { to have quality jobs. }\end{array}$ \\
\hline $\begin{array}{l}\text { 9. Industry, } \\
\text { innovation } \\
\text { and infrastructure }\end{array}$ & $\begin{array}{l}\text { Investments in infrastructure } \\
\text { are crucial to achieving sustain- } \\
\text { able development. }\end{array}$ \\
\hline $\begin{array}{l}\text { 10. Reduced } \\
\text { inequalities }\end{array}$ & $\begin{array}{l}\text { To reduce inequalities, policies } \\
\text { should be universal in princi- } \\
\text { ple, paying attention to the } \\
\text { needs of disadvantaged and } \\
\text { marginalized populations. }\end{array}$ \\
\hline $\begin{array}{l}\text { 11. Sustainable } \\
\text { cities and } \\
\text { communities }\end{array}$ & $\begin{array}{l}\text { There needs to be a future in } \\
\text { which cities provide opportuni- } \\
\text { ties for all, with access to basic } \\
\text { services, energy, housing, } \\
\text { transportation and more. }\end{array}$ \\
\hline $\begin{array}{l}\text { 12. Responsible } \\
\text { consumption and } \\
\text { production }\end{array}$ & $\begin{array}{l}\text { Responsible production and } \\
\text { consumption. }\end{array}$ \\
\hline 13. Climate action & $\begin{array}{l}\text { Climate change is a global chal- } \\
\text { lenge that affects everyone, } \\
\text { everywhere. }\end{array}$ \\
\hline $\begin{array}{l}\text { 14. Life below } \\
\text { water }\end{array}$ & $\begin{array}{l}\text { Careful management of this es- } \\
\text { sential global resource is a key } \\
\text { feature of a sustainable future. }\end{array}$ \\
\hline 15. Life on land & $\begin{array}{l}\text { Sustainably manage forests, } \\
\text { combat desertification, halt and } \\
\text { reverse land degradation, halt } \\
\text { biodiversity loss. }\end{array}$ \\
\hline $\begin{array}{l}\text { 16. Peace, justice } \\
\text { and strong } \\
\text { institutions }\end{array}$ & $\begin{array}{l}\text { Access to justice for all, and } \\
\text { building effective, accountable } \\
\text { institutions at all levels. }\end{array}$ \\
\hline $\begin{array}{l}\text { 17. Partnership for } \\
\text { the goals }\end{array}$ & $\begin{array}{l}\text { Revitalize the global partner- } \\
\text { ship for sustainable develop- } \\
\text { ment. }\end{array}$ \\
\hline
\end{tabular}

The approach of sustainable entrepreneurship has been raised to address the contribution of entrepreneurial activities to solving societal and environmental problems. Gerlach (2003) points out the necessity of approaching the analysis of the role of sustainable entrepreneurs for implementing sustainable development from the perspective of innovation. Successful sustainable innovation is accomplished when entrepreneurial actors achieve competitive advantages, i.e. economic success by applying innovative environmental and/or social practices. Companies are increasingly recognized as a driving force for innovation, entrepreneurial spirit and competitiveness, therefore, are seen as one of the keys to achieving sustainable development (Kardos, 2012).

\subsection{Entrepreneurship and sustainable development} Although both, sustainable development and entrepreneurship, are considered as the solutions for future development and progress, there are still relatively few articles, investigating both topics and their interconnections (Hall et al., 2010; Dhahri \& Omri, 2018). Entrepreneurship in the context of sustainable development has been addressed through various streams in the literature, among which are eco-preneurship, environmentally orientated entrepreneurship, social entrepreneurship, sustainable entrepreneurship (OECD, 2010).

Dean and McMullen (2007) state how economic activity is environmentally disruptive, satisfying the material needs of people, because it requires the use and disturbance of energy flows and materials, causing a negative impact on the environment, known as environmental degradation. But on the other hand, environmentally relevant market failures (e.g., public goods, externalities, monopoly power, inappropriate government intervention, and imperfect information) might represent opportunities for entrepreneurs simultaneously achieving profitability while reducing environmental degradation of economic behaviour (Riti et al., 2015). Also, Cohen and Winn (2007) develop the argument that four types of market imperfections contribute to environmental degradation and at the same time provide significant opportunities for the creation of radical technologies and innovative business models that contribute to sustainable development. They show, how these opportunities establish the foundations for an emerging model of sustainable entrepreneurship, one that enables founders to obtain entrepreneurial rents while simultaneously improving local and global social and environmental conditions.

This research contributes to this important emerging research area in that it clarifies conditions through which countries and companies can move toward more sustainable products and services. Following the above reasoning, we state the first hypothesis:

H1: Between entrepreneurial activity and sustainable development there exist statistically significant correlation. 


\subsection{Start-up entrepreneurship and sustainable de- velopment}

The particular subject of sustainable start-ups has received increasing interest with contributions from authors, such as Hockerts and Wüstenhangen (2010) and Parrish (2010), who investigated sustainabilitydriven entrepreneurship and start-ups. According to Hockerts and Wüstenhangen (2010), sustainable start-ups differ from conventional start-up companies in their pronounced value-based approach and intention to initiate social and environmental change in society.

For several years, entrepreneurship is recognized as a stimulus for solving sustainability problems (York \& Venkataraman, 2010; Pacheco et al., 2010). However, as the literature is relatively new to linking entrepreneurship and sustainable development, there are several issues, although there is a general premise, that entrepreneurial activity aimed at economic, social and environmental goals, contributes to the achievement of sustainability in the society (Hall et al., 2010). The first issue represents the level of analysis. Entrepreneurs and opportunities are representing one level of analysis (Shepherd \& Patzelt, 2011) while the second one represents a macro perspective (Cohen \& Winn 2007; Dean \& McMullen 2007). From a micro perspective, centre of analysis are individual entrepreneurs, who exhibit specific behaviours, among which are entrepreneurial intention (Kuckertz \& Wagner, 2010), opportunity recognition (Patzelt \& Shepherd, 2011), opportunity assessment (Shepherd et al, 2013) and entrepreneurial action (Meek et al., 2010). From a macro perspective, opportunities for sustainable entrepreneurship represent systemic imperfections or conditions (Pacheco et al., 2010) that make entrepreneurial opportunities possible to implement. On the other side, sustainable entrepreneurship should be reflected on a higher level of sustainable development on the macro level. Additionally, several authors discuss the nature of the value creation and outline the term sustainable entrepreneurship (Young \& Tilley, 2006; Cohen et al., 2008; Tilley \& Young, 2009; Muñoz \& Dimov, 2015). Some studies revealed that it depends on entrepreneurs' characteristics and intentions, whether they pursue sustainable start-ups or not (Kuckertz \& Wagner, 2010; Hall et al., 2010).

The second issue is related to the factors that drive entrepreneurial behaviour to sustainable development. In the literature, there can be found several factors, such as individual ones - prior knowledge (Patzel \& Shepherd, 2011), sustainability intention (Schaltegger \& Wagner, 2011; Muñoz \& Dimov, 2015) and sustainability orientation (Gibbs, 2009; Kuckertz \& Wagner, 2010; Muñoz \& Dimov, 2015). Other factors are contextual, among which are social norms (Meek et al., 2010; Muñoz \& Dimov, 2015), the openness of the business context to sustainability practices (De Clercq \& Voronov, 2011; Pacheco et al., 2010; Muñoz \& Dimov, 2015) and the promotion of the entrepreneurship ecosystem to pursue sustainable enterprises. Also, Dean and McMullen (2007) imply conceptualizations of sustainable entrepreneurship by proposing that environmentally relevant market failures represent opportunities for achieving profitability while simultaneously reducing environmentally degrading economic behaviour.

Furthermore, Youssef et al. (2018) state that proposing new services and products captures residual demand in the first step with a higher margin. The previous research has shown how green labelling was successful in developing these products in developed countries and the trend is following in developing countries. In their research, the authors came to the empirical results, which show that both formal and informal entrepreneurship are conducive to less environmental quality and sustainability in 17 African countries where the contribution of informal entrepreneurship is much higher compared to the formal one. In some cases, entrepreneurs may also face strong regulation that induces them to use more sustainable methods of production. In this case, opportunity entrepreneurs will take this opportunity to increase their market share or to enter new markets, which was not possible before the change of the regulation, and contribute to sustainable development. However, for necessity entrepreneurs, stronger regulation may represent such a barrier, that they may discontinue their entrepreneurship activity.

As there are numerous approaches to investigation on the linkages between entrepreneurship and sustainable development, in the paper, we will shift the perspective and use a holistic approach, analysing connections between entrepreneurship and sustainable development on a global level. In accordance with the above arguing, we state the following two hypotheses:

H2: Opportunity-driven entrepreneurial activity has a positive statistically significant impact on sustainable development.

H3: Necessity-driven entrepreneurial activity has a negative statistically significant impact on sustainable development.

\subsection{Innovation, entrepreneurship and sustainable development}

Entrepreneurship that aims at triple-bottom-line approach, obtains some characteristics, among which are social responsibility, competitiveness, progressiveness, knowledge creation and usage, innovativeness, dynamism and seeks for business benefits creating social value (Kriščiūnas \& Greblikaitè, 2007). As revealed by Schaltegger and Wagner (2011), such an ambitious approach of entrepreneurship, which on one side attempts to contribute to the sustainable development of the organisation itself, and on the other side to create a significant contribution of organizations to the sustainable development of society as a whole, requires significant innovations. Additionally, Gerlach (2003) points out the necessity of 
approaching the analysis of the role of entrepreneurs in contributing to sustainable development from the perspective of innovation. The focus lies on innovations that enhance sustainability (Kardos, 2012). A successful innovation that contributes to sustainable development is accomplished when entrepreneurs achieve competitive advantages by applying innovative environmental and/or social practices. However, Youssef at al. (2018) reveal, that the relationship between entrepreneurship and sustainable development becomes strongly positive when the levels of innovation and institutional quality are higher. Furthermore, they expose, that the opportunity recognition makes a basis for innovations, which play a key role in sustainable entrepreneurship. In line with the above discussion, stated is following the fourth hypothesis:

H4: Innovative entrepreneurial activity has a positive statistically significant impact on sustainable development.

\section{Methodology}

In the paper, the Global Entrepreneurship Monitor (GEM) database and Sustainable Development Goals (SDG) Index represent the data basis for the empirical testing of the hypotheses. The GEM database is the world's foremost study of entrepreneurship and the most recent secondary data were used for identification of the independent variables. Data given in this domain are collected on a yearly basis by the Adult Population Survey (APS), which is a comprehensive questionnaire, administered to a minimum of 2000 adults in each GEM country, designed to collect detailed information on the entrepreneurial activity, attitudes and aspirations of respondents (Bosma \& Kelley, 2018).

For the dependent variable, the data from the SDG Index and Dashboards Report 2018 were used. The report is published in July 2018 and represent an annual overview of countries' performance on the 17 Sustainable Development Goals prepared jointly by the Bertelsmann Stiftung and the Sustainable Development Solutions Network (Sachs et al., 2018). The research is cross-country. According to the availability covering of national level of data, it is done on a sample of 46 countries. The countries and their value of SDG Index are shown below in Table 2. The average SDG Index Score of included countries is 70.1. In the sample, the highest SDG score has Sweden (85.0), followed by Germany (82.3), France (81.2), Switzerland (80.1), Austria (80) and Slovenia (80), while scores of Angola (49.6), Sudan (49.6) and Madagascar (45.6) are way below the average (70.1). The literature review shows mixed results on impact of entrepreneurship on sustainable development, and on one side it suggests that entrepreneurship leads to less conducive sustainability due to having a negative impact on the environment, but on the other side the literature also suggests how such a situation
Table 2. SDG Index scores for research sample countries (Sachs et al., 2018, 23)

\begin{tabular}{|c|c|c|}
\hline Rank & Country & SDG Index Score \\
\hline 1 & Sweden & 85 \\
\hline 2 & Germany & 82 \\
\hline 3 & France & 81 \\
\hline 4 & Switzerland & 80 \\
\hline 5 & Austria & 80 \\
\hline 6 & Slovenia & 80 \\
\hline 7 & Netherlands & 80 \\
\hline 8 & United Kingdom & 79 \\
\hline 9 & Japan & 79 \\
\hline 10 & Ireland & 78 \\
\hline 11 & South Korea & 77 \\
\hline 12 & Canada & 77 \\
\hline 13 & Croatia & 77 \\
\hline 14 & Luxembourg & 76 \\
\hline 15 & Slovak Republic & 76 \\
\hline 16 & Spain & 75 \\
\hline 17 & Italy & 74 \\
\hline 18 & Poland & 74 \\
\hline 19 & Bulgaria & 73 \\
\hline 20 & United States & 73 \\
\hline 21 & Chile & 73 \\
\hline 22 & Greece & 71 \\
\hline 23 & Cyprus & 70 \\
\hline 24 & Uruguay & 70 \\
\hline 25 & Argentina & 70 \\
\hline 26 & China & 70 \\
\hline 27 & Brazil & 70 \\
\hline 28 & Thailand & 69 \\
\hline 29 & Russia & 69 \\
\hline 30 & Peru & 68 \\
\hline 31 & Colombia & 67 \\
\hline 32 & Morocco & 66 \\
\hline 33 & Turkey & 66 \\
\hline 34 & Iran & 66 \\
\hline 35 & Panama & 65 \\
\hline 36 & Lebanon & 65 \\
\hline 37 & Egypt & 64 \\
\hline 38 & Saudi Arabia & 63 \\
\hline 39 & United Arab Emirates & 63 \\
\hline 40 & Indonesia & 63 \\
\hline 41 & Qatar & 61 \\
\hline 42 & India & 59 \\
\hline 43 & Guatemala & 58 \\
\hline 44 & Angola & 50 \\
\hline 45 & Sudan & 50 \\
\hline 46 & Madagascar & 46 \\
\hline
\end{tabular}

could represent the new opportunities for entrepreneurs to create innovative product and services. To examine those claims and relation of entrepreneurship to sustainable development, the following variables from the databases GEM (Bosma \& Kelley, 2018) and SDG Index and Dashboards Report (Sachs et al., 2018) were identified and labelled as follows:

- $\mathrm{x}_{1}$-total early-stage entrepreneurial activity (TEA Index): percentage of the 18-64 population who are either a nascent entrepreneur (actively involved in setting up a business they will own or co-own; this business has not paid sala- 
Figure 1. Graphical form of hypotheses

\begin{tabular}{|c|c|c|}
\hline TEA Index & SDG Index \\
\hline Opportunity-driven entrepreneurial activity & SDG Index \\
\hline Necessity-driven entrepreneurial activity & SDG Index \\
\hline Innovative entrepreneurial activity & S & SDG Index \\
\hline
\end{tabular}

ries, wages, or any other payments to the owners for more than three months) or owner-manager of a new business (currently owner-manager of a new business, i.e., owning and managing a running business that has paid salaries, wages, or any other payments to the owners for more than three months, but not more than 42 months);

- $\quad \mathrm{X}_{2}$-opportunity-driven entrepreneurial activity as the percentage of TEA Index: percentage of those involved in TEA who are either a nascent entrepreneur owner-manager of new business because of the good opportunities to start a firm in the area where they live;

- $\quad \mathrm{x}_{3}-$ necessity-driven entrepreneurial activity as the percentage of TEA Index: percentage of those involved in TEA who are either a nascent entrepreneur owner-manager of new business because there were no jobs or other sources of income;

- $\quad \mathrm{X}_{4}$-innovative entrepreneurial activity: percentage of TEA who indicate that their product or service is new to some or all customers and is offered by few or no other competitors;

- y- SDG Index: dependent variable: measured by 17 goals, which are weighted equally in the common Index; the score signifies a country's position between the worst (0) and the best (100) outcomes.

The hypothesis $\mathrm{H} 1$ is going to be tested by the Person's correlation coefficient. The testing of the hypotheses $\mathrm{H} 2, \mathrm{H} 3$ and $\mathrm{H} 4$ is going to be done by the regression analysis. For the analysis, the SPSS Statistics statistical software was used. In Figure1, the hypotheses are provided in the graphical form and the regression model is shown in its stochastic form. Regression model in a stochastic form for testing $\mathrm{H} 2$, $\mathrm{H} 3$ and $\mathrm{H} 4$ hypotheses:

$y=\beta_{0}+\beta_{n} x_{n}+e$

where are:

$y$-dependent variable; $\beta_{0}, \beta_{n}$, - value of the regression coefficients; $\mathrm{n}=1,2,3 ; x_{\mathrm{n}}-$ independent variables; $\mathrm{n}=1,2,3$; $\mathrm{e}-$ residual

\section{Empirical results and discussion}

In this section, the results of the testing hypotheses are presented and discussed.
To test the first hypothesis H1, the correlation analysis is made. Results are shown in Tables 3 and 4, where the descriptive statistics (Table 3 ) as well as results of the Pearson correlation (Table 4) are shown. The sample size is $\mathrm{N}=46$.

Table 3. Descriptive statistics results

\begin{tabular}{|l|c|c|c|}
\hline & Mean & $\begin{array}{c}\text { Std. } \\
\text { Deviation }\end{array}$ & N \\
\hline $\begin{array}{l}\text { total early-stage entre- } \\
\text { preneurial activity (x1) }\end{array}$ & 12.72 & 7.508 & 46 \\
\hline SDG Index (y) & 70.0978 & 8.79597 & 46 \\
\hline
\end{tabular}

Table 4. Results of correlation analysis

\begin{tabular}{|c|c|c|c|}
\hline \multicolumn{2}{|c|}{ (n) } & $\mathbf{x 1}$ & $\mathbf{y}$ \\
\hline \multirow[t]{3}{*}{$\mathbf{x 1}$} & Pearson Correlation & 1 & $-0.579^{* *}$ \\
\hline & Sig. (2-tailed) & & 0.000 \\
\hline & $\mathrm{N}$ & 46 & 46 \\
\hline \multirow[t]{3}{*}{$\mathbf{y}$} & Pearson Correlation & & 1 \\
\hline & Sig. (2-tailed) & & \\
\hline & $\mathrm{N}$ & & 46 \\
\hline
\end{tabular}

Taking the results into the account, there is a statistically significant correlation between entrepreneurial activity, measured by TEA Index, and sustainable development, measured by SDG Index. The correlation between variable $\mathrm{x}_{1}$ (TEA index) and variable $\mathrm{y}$ (SDG Index) is negative, moderate (Keller \& Warrack, 2000) and statistically significant at $\mathrm{p}<0.01$. The correlation is negative $(-0.579)$, indicating that when SDG Index increases the total early-stage entrepreneurial activity rate decreases and vice versa. Based on the above presented results the hypothesis $\mathrm{H} 1$, that between entrepreneurial activity and sustainable development exists statistically significant correlation, can be accepted.

To test the hypotheses H2, H3 and H4 the simple linear regression was used. In Table 5, the results of the regression model 1 are presented to test the second hypothesis (H2) according to which the opportunitydriven entrepreneurial activity has a positive impact on sustainable development.

Results show, that for variable $\mathrm{x}_{2}$ (opportunity entrepreneurial activity) regression coefficient $\left(\beta_{l}=0.356\right)$ is positive and statistically significant $(\mathrm{p}=0.005$; $\mathrm{p}<0.05$ ). The correlation coefficient $\mathrm{R}$ between the dependent variable and the independent variable is 0.405 . In addition, the determination coefficient $\left(\mathrm{R}^{2}=0.164\right)$ indicates that $16 \%$ of the variance of the 
Table 5. Results of simple regression analysis of opportunity-driven entrepreneurial activity indicator and SGD Index

\begin{tabular}{|l|c|c|c|c|c|}
\hline Model 1 & B & Std. Error & Beta & t & Sig. \\
\hline (Constant) & 44.638 & 8.751 & & 5.101 & 0.000 \\
\hline $\mathrm{x} 2$ & 0.356 & 0.121 & 0.405 & 2.937 & 0.005 \\
\hline $\mathrm{R}$ & 0.405 & & & \\
\cline { 1 - 2 } R square & 0.164 & & & \\
\cline { 1 - 2 } Std. Error of the Estimate & 8.13375 & & & \\
\cline { 1 - 2 } F-test (Sig.) & $8.626^{*}$ & & & \\
*note: statistically significant at $\mathrm{p}=0.005$ &
\end{tabular}

Table 6. Results of simple regression analysis of necessity-driven entrepreneurial activity indicator and SGD Index

\begin{tabular}{|l|c|c|c|c|c|}
\hline Model 2 & B & Std. Error & Beta & t & Sig. \\
\hline (Constant) & 80.379 & 2.686 & & 29.928 & 0.000 \\
\hline x3 & -0.445 & 0.106 & -0.535 & -4.202 & 0.000 \\
\hline R & 0.535 & & & \\
\hline R square & 0.286 & & & \\
\cline { 1 - 2 } Std. Error of the Estimate & 7.51440 & & & \\
\cline { 1 - 2 } F-test (Sig.) & $17.658^{*}$ & &
\end{tabular}

Table 7. Results of simple regression analysis of innovative entrepreneurial activity indicator and SGD Index

\begin{tabular}{|l|c|c|c|c|c|}
\hline Model 3 & B & Std. Error & Beta & t & Sig. \\
\hline (Constant) & 64.151 & 3.405 & & 18.842 & 0.000 \\
\hline X4 & 0.226 & 0.120 & 0.273 & 1.881 & 0.067 \\
\hline R & 0.273 & & & \\
\cline { 1 - 2 } R square & 0.074 & & & \\
\cline { 1 - 2 } Std. Error of the Estimate & 8.55803 & & & \\
F-test (Sig.) & $3.537 *$ & &
\end{tabular}

SDG Index (dependent variable) is explained by the independent variable, included in the model. Also, the F-test value of the model $(\mathrm{F}=8.626 ; \mathrm{p}=0.005)$, indicates that a variable is significant, and thus indicates that the complete model is valid. The results of the regression analysis of the hypothesis $\mathrm{H} 2$ according to which the opportunity-driven entrepreneurial activity positively impacts sustainable development, can be confirmed.

Results show, that for variable $\mathrm{x}_{3}$ (necessity entrepreneurial activity) regression coefficient $\left(\beta_{1}=-\right.$ $0.445)$ is negative and statistically significant $(\mathrm{p}=0$; $\mathrm{p}<0.05)$. The determination coefficient $\left(\mathrm{R}^{2}=0.286\right)$ indicates that $28.6 \%$ of the variance of the SDG Index (dependent variable) is explained by the independent variable, included in the model 2 . The F-test value is large $(\mathrm{F}=17.658)$, what indicates that most of the variation in the dependent variable is explained by the regression equation and the $p$-value is 0 , what infer that the model is valid. In regard to the results of regression analysis of the hypothesis $\mathrm{H} 3$, according to which the necessity-driven entrepreneurial activity negatively impacts sustainable development, can be confirmed.

In Table 7, the results of the regression model 3 are presented by testing the third hypothesis, according to which the innovative entrepreneurial activity has a positive impact on sustainable development.

Results show, that for variable $\mathrm{x}_{4}$ (innovative entrepreneurial activity) regression coefficient $\left(\beta_{1}=0.226\right)$ is positive, but too small to be statistically significant $(\mathrm{p}=0.067 ; \mathrm{p}<0.05)$. The determination coefficient $\left(\mathrm{R}^{2}=0.074\right)$ indicates that only $7.4 \%$ of the variance of the SDG Index (dependent variable) is explained by the independent variable, included in model 3 . The F-test value of the model $(\mathrm{F}=3.537 ; \mathrm{p}=0.067)$ also indicates that a model is not valid. Thus, regarding the results of regression analysis for testing the hypothesis $\mathrm{H} 4$, according to which the innovative entrepreneurial activity positively impacts sustainable development, cannot be confirmed.

The above results could be explained by the fact that TEA considers entrepreneurs who run the business not more than 42 months and the reason might be that those entrepreneurs in early-stage of entrepreneurial activity are using less innovative solutions and less environment-friendly technologies and methods of production, which are not subject to high environmental standards. While on the other hand, according to the results, opportunity-driven entrepreneurial activity and innovative entrepreneurial activity show positive relations to SDG Index.

The results show that the opportunity-driven entrepreneurial activity has a positive impact on sustainable development, while the necessity-driven entrepreneurship has a negative impact on sustainable development what is in line with some previous research (Kuckertz \& Wagner, 2010). As opportunitydriven entrepreneurs more likely to pursue their start-ups to implement an opportunity seen in their environment. In addition, they are more motivated 
from their intentions and consequently are more sustainably and long-term oriented. As found by Youssef et al. (2018) in African countries, opportunity-driven entrepreneurship contributes to sustainable development. On the other side, necessitydriven entrepreneurs also pursue their start-ups, because in their environment there are not available job options. Those individuals do not become entrepreneurs to implement a promising business opportunity, but rather to earn an income. Consequently, they are not motivated by the opportunity, but by income for their surviving. So, they are more shortterm oriented, unlike opportunity-driven entrepreneurs.

To achieve the overall objective of sustainable development, the countries should make special efforts to consider the implementation of SDGs as the national priority and integrate them into the national strategies. This requires transformations and improvement of many dimensions and sectors (e.g. changes in budgets, regulatory, procurement policies, energy use, land use, urban planning, education, research and development, etc.) in the national economy. Each transformation requires great support from policymakers (government) especially by introducing new policies and measures, private sector (business) and civil society. According to our empirical results in the research, it appears that entrepreneurship represents an important factor for fostering sustainability, but the success lies in opportunitydriven entrepreneurial activities as well as in innovative entrepreneurial activity.

\section{Conclusion}

Based on the literature review, the paper provides insight into the linkages between entrepreneurial activity and sustainable development. As the topic is relatively new, there are still many open questions and gaps to be fulfilled, mainly missing empirical evidence. Additionally, scarce empirical evidence provides mixed results regarding the impact of entrepreneurship on sustainable development. Therefore, our paper contributes to fill in the mentioned gap in the literature by providing a quantitative analysis of linkages and impacts between entrepreneurial activity and sustainable development on the international level. According to empirical results in our study, we confirmed the linkages between entrepreneurship activity and sustainable development. However, to get an in-depth insight into the linkages, we tested particular types of entrepreneurship and their impacts on sustainable development. In our study, it appears that particular types of entrepreneurial activity have a different impact on sustainable development. The results indicate that the opportunity-driven and innovative entrepreneurial activity positively impact sustainable development, while the necessity-driven entrepreneurial activity indicates the negative impact. Accordingly, our results provide strong support for the argument that the entrepreneurial activity interrelates with sustainable development. The findings contribute to the entrepreneurial economic literature by providing an empirical approach, which confirms the assumption that entrepreneurship impacts sustainable development. This approach, not only contributes to the existing literature, but also conducts policy and managerial implications for implementing the sustainable development goals, by supporting particular types of entrepreneurial activity. However, the limitation of our study, by measuring only direct linkages between the mentioned concepts and the sample of countries provide the origin for future research directions. Regarding sustainable development goals, different indicators related to the economic, social, and environmental objectives could be analysed in future studies. Also, our study only examines the direct effects of entrepreneurship on the pillars of sustainable development. The process toward sustainable entrepreneurship is complex and it might take place through several steps. For this reason, as some of the previous studies also suggest, the entrepreneurship cannot simultaneously achieve sustainability goals without implementing appropriate ecosystem conditions. Thus, future studies might extend this research by employing mediating or moderating models to examine the conditions through which entrepreneurship could achieve these objectives.

\section{References}

1. BOSMA N., KELLY D., 2018, Global entrepreneurship monitor: 2018/2019 Global Report, Babson College, USA.

2. COBBINAH P.B., BLACK R., THWAITES R., 2011, Reflections on six decades of the concept of development: Evaluation and future research, in: Journal of Sustainable Development in Africa, 13(7), p. 134-149.

3. COHEN B., WINN M.I., 2007, Market imperfections, opportunity and sustainable entrepreneurship, in: Journal of Business Venturing, 22(1), p. 29-49.

4. DE CLERCQ D.D., VORONOV M., 2011, Sustainability in entrepreneurship: a tale of two logics, in: International Small Business Journal, 29(4), p. 322344.

5. DEAN T.J., MCMULLEN J.S., 2007, Toward a theory of sustainable entrepreneurship: Reducing environmental degradation through entrepreneurial action, in: Journal of business venturing, 22(1), p. 5076.

6. DHAHRI S., OMRI A., 2018, Entrepreneurship contribution to the three pillars of sustainable development: what does the evidence really say?, in: World Development, 106, p. 64-77.

7. DOMAŃSKA A., ŻUKOWSKA B., ZAJKOWSKI R., 2018, Green Entrepreneurship as a Connector among Social, Environmental and Economic Pillars of Sustainable Development. Why Some Countries are More Agile?, in: Problemy Ekorozwoju/ Problems of sustainable development, 13(2), p. 67-76.

8. ELKINGTON J., 1998, Partnerships from cannibals with forks: The triple bottom line of 21 st-century 
business, in: Environmental quality management, 8(1), p. 37-51.

9. EMAS R., 2015, Brief for GSDR, 2015: The concept of sustainable development: definition and defining principles, https://sustainabledevelopment.un.org/co ntent/documents/5839GSDR\%202015_SD_concept _definiton_rev.pdf (2.10.2019).

10. GERLACH A., 2003, Sustainable entrepreneurship and innovation, in: Proceedings of the Corporate Social Responsibility and Environmental Management Conference, Leeds, UK, 29-30 June 2003, p. 38-49.

11. GIBBS D., 2009, Sustainability entrepreneurs, ecopreneurs, and the development of a sustainable economy, in: Greener Management International, 55, p. 63-78.

12. HALL J.K., DANEKE G.A., LENOX M.J., 2010, Sustainable development and entrepreneurship: Past contributions and future directions, in: Journal of Business Venturing, 25(5), p. 439-448.

13. HART S.L., MILSTEIN M.B., 2003, Creating sustainable value, in: Academy of Management Perspectives, 17(2), p. 56-67.

14. HOCKERTS K., WÜSTENHAGEN R., 2010, Greening Goliaths versus emerging Davids - Theorizing about the role of incumbents and new entrants in sustainable entrepreneurship, in: Journal of Business Venturing, 25(5), p. 481-492.

15. KARDOS M., 2012, The Relationship between Entrepreneurship, Innovation and Sustainable Development. Research on European Union Countries, in: Procedia Economics and Finance, 3, p. 1030-1035.

16. KELLER G., WARRACK B., 2000, Inference about the comparisons of two populations, in: Statistics for Management and Economics, 5, p. 394-470.

17. KRIŠČIŪNAS K., GREBLIKAITĖ J., 2007, Entrepreneurship in sustainable development: SMEs Innovativeness in Lithuania, in: Inžinerine ekonomika, 54(4), p. 20-26.

18. KUCKERTZ A., WAGNER M., 2010, The influence of sustainability orientation on entrepreneurial intentions - Investigating the role of business experience, in: Journal of Business Venturing, 25(5), p. 524-539.

19. MEEK W.R., PACHECO D.F., YORK J.G., 2010, The impact of social norms on entrepreneurial action: Evidence from the environmental entrepreneurship context, in: Journal of Business Venturing, 25(5), p. 493-509.

20. MUÑOZ P., DIMOV D., 2015, The call of the whole in understanding the development of sustainable ventures, in: Journal of Business Venturing, 30(4), p. 632-654

21. OECD, 2010, SMEs, Entrepreneurship and Innovation, OECD Studies on SMEs and Entrepreneurship, OECD Publishing, Paris.
22. PACHECO D.F., DEAN T.J., PAYNE D.S., 2010, Escaping the green prison: Entrepreneurship and the creation of opportunities for sustainable development, in: Journal of Business Venturing, 25(5), p. 464-480.

23. PARRISH B.D., 2010, Sustainability-driven entrepreneurship: Principles of organization design, in: Journal of Business Venturing, 25(5), p. 510523.

24. PATZELT H., SHEPHERD D.A., 2011, Recognizing opportunities for sustainable development, in: Entrepreneurship Theory and Practice, 35(4), p. 631652.

25. RITI J.S., DANKUMO A.M., GUBAK H.D., 2015, Entrepreneurship and Environmental Sustainability: Evidence from Nigeria, in: Journal of Economics and Sustainable Development, 6(8), p. 130-140.

26. SACHS J., SCHMIDT-TRAUB G., KROLL C., LAFORTUNE G., FULLER G., 2018, SDG Index and Dashboards Report 2018, Bertelsmann Stiftung and Sustainable Development Solutions Network, New York.

27. SCHALTEGGER S., WAGNER M., 2011, Sustainable entrepreneurship and sustainability innovation: categories and interactions, in: Business strategy and the environment, 20(4), p. 222-237.

28. SHEPHERD D.A., PATZELT H., 2011, The new field of sustainable entrepreneurship: Studying entrepreneurial action linking 'what is to be sustained' with 'what is to be developed', in: Entrepreneurship Theory and Practice, 35(1), p. 137-163.

29. SHEPHERD D.A., PATZELT H., BARON R.A., 2013, 'I care about nature, but...': Disengaging values in assessing opportunities that cause harm, in: Academy of Management Journal, 56(5), p. 12511273.

30. STEFANESCU D., ON, A., 2012, Entrepreneurship and sustainable development in European countries before and during the international crisis, in: Procedia-Social and Behavioral Sciences, 58, p. 889898.

31. YORK J.G., VENKATARAMAN S., 2010, The entrepreneur-environment nexus: Uncertainty, innovation, and allocation, in: Journal of business Venturing, 25(5), p. 449-463.

32. YOUNG W., TILLEY F., 2006, Can businesses move beyond efficiency? The shift toward effectiveness and equity in the corporate sustainability debate, in: Business Strategy and the Environment, 15(6), p. 402-415.

33. YOUSSEF A.B., BOUBAKER S., OMRI A., 2018, Entrepreneurship and sustainability: The need for innovative and institutional solutions, in: Technological Forecasting and Social Change, 129, p. 232-241. 
